carcinoma. The differential diagnoses include squamous cell carcinoma of the anal canal with mucinous histiocytes, apocrine carcinoma and Paget's disease of the perianal skin. An adenocarcinoma of the rectum may extend into the anal canal but is likely to be associated with an obvious intraluminal tumour. The association of carcinoma with fistula-in-ano is well known: this occurs when a chronic fissure or fistula has been present for 20 years or more. The carcinoma which develops is often colloid in type, with considerable mucin production. ${ }^{2}$ These cases have to be distinguished from invasive carcinomas presenting as non-healing fistulae $^{3}$ which have a much shorter history.

Reported cases of anal gland carcinoma have attracted controversy previously because of the difficulty in demonstrating a site of origin. ${ }^{23}$ The diagnosis can only be made with certainty when the anal glands show in situ neoplastic change, as in the two cases presented here.

Our thanks are due to our surgical colleagues, Mr D J Galloway and Professor W D George, for permission to publish their cases.

1 Wellman RF. Adenocarcinoma of anal duct origin. Can 7

Surg 1962;5:311-18.
Winkleman J, Grosfeld J, Bigelow B. Colloid carcinoma of anal gland origin. Report of a case and review of the literature. Am f Clin Pathol 1964;45:395-401.

3 Tarazi R, Nelson RL. Anal adenocarcinoma: a comprehensive review. Semin Surg Oncol 1994;10:235-40.

4 Abel ME, Chiu YSY, Russell TR, Volpe PA. Adenocarcinoma of the anal glands: Results of a survey. Dis Colon Rectum 1993;36:383-7.

5 Fenger C, Filipe MI. Mucin histochemistry of the anal canal of epithelium. Studies of normal anal mucosa and mucosa epithelium. Studies of normal anal mucosa and mucosa $\vec{O}$ adjacent to carcinoma. Histochem f 1981;13:921-30.

6 Grinvalsky HT, Helwig EB. Carcinoma of the anal function. Histologic considerations. Cancer 1956;9:480-8.

7 Rosser C. The relation of fistula in ano to cancer of the anal canal. Trans Am Proct Soc 1934;35:65-71.

\title{
Leukaemia of natural killer cell large granular lymphocyte type with HLA-DR ${ }^{-} \mathrm{CD} 16^{-} \mathrm{CD} 56^{\text {bright+ }}$ phenotype
}

\author{
J Prieto, E Ríos, A Parrado, A Martín, J M de Blas, J M Rodríguez
}

\section{Servicio de Hematología y Hemoterapia, Hospital Universitario Virgen del Rocío, Servicio Andaluz de Salud, Sevilla, Spain \\ Correspondence to: Dr Prieto, Servicio de Hematología y Hemoterapia, Hospital Universitario Virgen del Rocío, Avda Manuel Siurot s/n, 41013 Sevilla, Spain.}

\begin{abstract}
The case is reported of a 45 year old woman with the rare leukaemia of natural killer cell large granular lymphocyte (NKJ LGL) type. Cytometric analysis of leukaemic blasts showed that they were positive for CD2, CD38, and CD56 antigens but negative for a series of antigens including CD3, CD7, CD16, and HLA-DR. Rearrangements of the $\beta T$ cell receptor, and heavy and $\kappa$ immunoglobulin genes were not detected and neither were chromosomal abnormalities. Leukaemic blasts developed NK cytotoxicity. The patient failed to respond to aggressive chemotherapy and died three months after diagnosis. The lack of expression of HLA-DR is an extraordinary characteristic of this case, as all cases of acute NK cell leukaemias described to date expressed HLADR. The immunophenotype observed in the NK cell leukaemic blasts may represent the counterpart of a hypothetical normal cell precursor in an early stage of ontogenic NK cell development.

(F Clin Pathol 1996;49:1011-1013)
\end{abstract}

Keywords: natural killer, acute leukaemia, immunophenotype, development.
Natural killer (NK) cell proliferative disorders are very infrequent diseases that can be classified into chronic ${ }^{1}$ and acute ${ }^{2}$ forms. Acute NK cell leukaemia, referred to as NK/LGL leukaemia, has been described mainly in Japanese patients, although some European cases have been reported. NK cells express the $\mathrm{CD}^{-} \mathrm{CD}^{-} 6^{+}$or $\mathrm{CD}^{-} \mathrm{CD} 16^{+}$phenotypes, or both, and normally exist in the bone marrow, 을 peripheral blood, and spleen. NK cells develop $\frac{7}{0}$ cytolytic activity against cells infected with viruses and also against certain tumour targets $N$ in a way not restricted to the expression of molecules of the major histocompatibility complex (MHC) on the target cell. ${ }^{3}$ All the cases of NK/LGL leukaemia so far described present the $\mathrm{CD}^{-} \mathrm{CD} 16^{ \pm} \mathrm{CD} 56^{ \pm} \mathrm{HLA}-\mathrm{DR} \mathrm{R}^{+}$ phenotype. ${ }^{24}$ In this paper we present a case of $\stackrel{\mathscr{?}}{+}$ NK/LGL leukaemia with $\mathrm{CD}^{-} \mathrm{CD} 16^{-}$ CD56 ${ }^{\text {bright }}$ HLA-DR ${ }^{-}$phenotype.

\section{Case report}

A 45 year old woman was admitted with a high fever (but without signs of infection), cephalea and myalgia, and moderate splenomegaly. Her haematometric results were: haemoglobin 75 $\mathrm{g} / \mathrm{l}$, leucocyte count of $2.3 \times 10^{9} / 1$, with a differential count of $57 \%$ segmented neutrophils, $5 \%$ monocytes, $26 \%$ lymphocytes, and $12 \%$ blasts with LGL morphology, and a platelet count of $90 \times 10^{9} / 1$. Two days later her 
pancytopenia had progressed: haemoglobin 60 $\mathrm{g} / \mathrm{l}$, leucocyte count of $1.2 \times 10^{9} / 1$, and a platelet count of $30 \times 10^{9} / 1$. Twenty days before entering hospital her laboratory analytical results were normal. The bone marrow aspirate was hypocellular with a $61 \%$ infiltration of blasts. The blasts presented a pleomorphic appearance with a very irregular nuclear and cellular outline, a moderately loose chromatin, and an abundant basophilic cytoplasm with small to medium sized azurophilic granules with a mainly centrosomic localisation. Few cells had a visible nucleolus. Ninety five percent of the blasts were acid phosphatase positive with a centrosomic granular pattern, and $7 \%$ were positive for periodic acid Schiff in the form of isolated granules. The blasts were negative for myeloperoxidase, Sudan black B, $\alpha$-naphtyl acetate esterase, and chloroacetateesterase. Electron microscopic examination showed that the nuclei of the blasts were irregular in outline, had heterochromatin accumulations and frequently nucleoli, and that the cytoplasm had a prominent granulation with isolated bundles of microfibrils. No karyotypic abnormalities were detected using chromosomal banding techniques. Southern blot analysis, using biotin labelled $\mathrm{J}_{\beta} \mathrm{I}-\mathrm{J}_{\beta} \mathrm{II}, \mathrm{J}_{\mathrm{H}}$, and $\mathrm{J}_{\kappa}$ probes (Oncor, Gaithersburg, Maryland, USA) revealed that the $\beta \mathrm{T}$ cell receptor (TCR), and heavy and $\kappa$ immunoglobulin (Ig) genes were in germline configuration. These findings, together with immunophenotypic studies and analyses of cytolytic activity of the blasts, justified a diagnosis of NK/LGL leukaemia. Because of the poor response of the patient to the treatment followed in cases described in published reports, she was considered to be at high risk. Treatment with daunorubicin, prednisone, cyclophosphamide, vincristine, and $\mathrm{L}$-asparaginase was initiated but complete remission was not achieved. The patient then received dexamethasone, vincristine, L-asparaginase, and high doses of cytosine arabinoside and methotrexate. She died of a pulmonary infection three months after diagnosis, in a phase of pancytopenia. Three days before death the bone marrow aspirate was hypocellular with a $97 \%$ blast infiltration.

\section{IMMUNOPHENOTYPIC ANALYSIS}

Surface marker analysis was done by double immunofluorescence flow cytometry. The following fluorescein isothiocyanate (FITC) or phycoerythrin (PE) conjugated monoclonal antibodies were used: anti-CD1 (OKT-6), CD2 (Leu-5b), CD3 (Leu-4), CD4 (Leu-3), CD5 (Leu-1), CD7 (Leu-9), CD8 (Leu-2), CD11b (Leu-15), CD11c (Leu-M5), CD13 (Leu-M7), CD14 (Leu-M3), CD15 (LeuM1), CD16 (Leu-11), CD19 (Leu-12), CD20 (Leu-16), CD22 (Leu-14), CD33 (Leu-M9), CD36 (OKM-5), CD38 (Leu-17), CD42b (DAKO-CD42b), CD56 (Leu-19), CD57 (Leu-7), CD61 (Dako-IIIa), CD71 (DakoCD71), and myeloperoxidase (Dako-MPO). The OK series was manufactured by Ortho Diagnostics, Raritan, New Jersey, USA, the Leu series by Becton Dickinson, San Jose, California, USA, and Dako series by Dako,
Glostrup, Denmark. The panel of monoclonal antibodies studied also included: anti-CD10 (CALLA), CD25, CD34 (HPCA-2), HLADR, TCR $\alpha \beta$, and TCR $\gamma \delta$ from Becton Dickinson; c-kit, TdT, and glycophorin-A from Immunotech, Marseille, France; and polyclonal anti- $\kappa$ and anti- $\lambda$ antibodies from Dako.

Bone marrow leukaemic blasts were isolated by Ficoll density gradient centrifugation and suspended to a concentration of $4 \times 10^{6} / \mathrm{ml}$ in phosphate buffered saline (PBS) with 10 $\mathrm{mg} / \mathrm{ml}$ bovine serum albumin. A volume of 100 $\mathrm{ml}$ cell suspension was incubated with $20 \mathrm{mg}$ of each monoclonal antibody for 30 minutes at $4^{\circ} \mathrm{C}$ in the dark. Cells were washed and suspended in $100 \mathrm{ml} \mathrm{PBS}$ containing $1 \mathrm{mg} / \mathrm{ml}$ sodium azide. Percentages of fluorescent labelled cells were determined from 10000 adquired cells on a FACScan flow cytometer (Becton Dickinson).

\section{CYTOTOXICITY ASSAY}

The human erythroid K562 and lymphoid Raji cell lines were used as targets to measure NK and spontaneous LAK activity, respectively, as described previously. ${ }^{5}$ Briefly, the patient's mononuclear cells, obtained by Ficoll density gradient centrifugation, and $5 \times 10^{6}$ target cells were labelled by incubation with $100 \mathrm{mCi}{ }^{51} \mathrm{Cr}$ for 90 minutes. In triplicate, varying numbers of patient's leukaemic cells and $5 \times 10^{3}$ target cells were co-cultured at ratios of $40: 1$ and $80: 1$ in RPMI-1640 medium containing $10 \%$ fetal calf serum in 96 -well round bottomed microtitre plates for four hours. Control wells containing target cells alone in the medium or $2 \%$ sodium dodecyl sulphate (SDS) were used to measure spontaneous release (SR) and maximum release (MR) of chromium, respectively. The supernatants were collected using the Skatron supernatant collection system and measured in a gamma counter. The percentage of experimental lysis was calculated according to the formula: \% lysis $=100 \times(\mathrm{ER}-\mathrm{SR}) /(\mathrm{MR}$ - SR), where ER represents experimental release of ${ }^{51} \mathrm{Cr}$.

\section{Results}

Cytometric analysis of the leukaemic blasts revealed that they were positive for the CD2 (96\%), CD38 (83\%) and CD56 (96\%) antigens, but negative $(0 \%)$ for the other markers studied. The negativity for the HLA-DR marker was confirmed using the alkaline phosphatase anti-alkaline-phosphatase (APAAP) technique.

The blasts developed high levels of NK activity ( $36 \%$ and $52 \%$ lysis on $\mathrm{K} 562$, at ratios of $40: 1$ and $80: 1$, respectively) and of spontaneous LAK activity (59\% and $68 \%$ lysis on Raji, respectively).

\section{Discussion}

We describe a case of the rare NK/LGL leukaemia with a $\mathrm{CD}^{-} \mathrm{CD} 16^{-} \mathrm{CD} 56^{\text {bright+ }} \mathrm{im}$ munophenotype. According to our data, approximately $5 \%$ of the NK cells in the peripheral blood of normal individuals present the same phenotype. Although the ontogenic 
development of the NK cells has not been elucidated, it has been suggested that these cells could be precursors of those with the CD $3^{-} \mathrm{CD} 16^{+} \mathrm{CD} 56^{\mathrm{dim}+}$ phenotype, which are the main NK cells in normal individuals. Increased counts of $\mathrm{NK} \mathrm{CD}^{-} \mathrm{CD} 16^{-}$ CD56 $6^{\text {bright+ }}$ cells have been reported in a group of patients after bone marrow transplant or treatment with interleukin $2,{ }^{6-8}$ suggesting that these procedures could mobilise these hypothetical precursor cells towards the circulating blood.

The phenotypes of tumour cells have often permitted the prediction of unknown links in $T$ and $B$ lymphoid differentiation. We believe that the phenotype in NK cell leukaemias could also provide clues for elucidating the ontogeny of NK cells. One antigenic characteristic common to all the NK/LGL leukaemias described in published reports, including our patient, is the lack of expression of CD7. This is a surface antigen expressed by normal $\mathrm{T}$ and NK cells. Some models postulate that in the differentiation of the NK cells, the expression of CD7 might be a very early occurrence, ${ }^{910}$ as is the case in $\mathrm{T}$ cell differentiation. Less than $2 \%$ of the NK cells in the peripheral blood of normal subjects have the $\mathrm{CD}^{-} \mathrm{CD} 56^{+}$phenotype, supporting the probability that these are early precursors of $\mathrm{CD} 7^{+} \mathrm{CD} 56^{+} \mathrm{NK}$ cells. However, the absence of CD7 in the leukaemic NK cells might indicate that this marker is expressed in NK cells following the expression of other markers, such as CD2 or CD56, which are expressed in all the cases of NK/LGL leukaemia reported to date.

HLA-DR is not expressed by the majority of normal NK cells, only by activated ones, so it should not be surprising that this feature is absent in our patient. The curious fact is that our patient is the only one who did not express HLA-DR among all the cases of NK/LGL leukaemias studied. In patients treated with interleukin 2 , a small but significant $(2-3 \%$ of peripheral blood lymphocytes) proportion of cells with the $\mathrm{CD}^{-} \mathrm{CD}^{-} \mathrm{CD} 8^{-} \mathrm{CD} 16^{-} \mathrm{CD} 56^{++}$ HLA-DR ${ }^{-}$phenotype can be measured, ${ }^{8}$ showing that this cell type exists in the peripheral blood, at least when given certain stimuli. The neoplastic cells observed in our patient could represent a leukaemic counterpart of this hypothetical NK cell precursor.

The present case had clinical and haematological features similar to typical Japanese NK/LGL leukaemia, which suggests it is the same entity presenting in a European patient We conclude that the rare occurrence of NK/LGL leukaemia and the peculiar immunophenotype of the blast cells, which as far as we know is the first to be described, lends special interest to the present case.

1 Tefferi A, Li CY, Witzig TE, Dhodapkar MV, Okuno SH, Phyliky RL. Chronic natural killer cell lymphocytosis: a descriptive clinical study. Blood 1994;84:2721-5.

2 Imamura N, Kusunoki Y, Kawa-Ha K, Yumura K, Hara J, Oda $\mathrm{K}$, et al. Aggressive natural killer cell leukaemia/ lymphoma: report of four cases and review of the literature. Possible existence of a new clinical entity originating from the third lineage of lymphoid cells. Br $\mathcal{F}$ Haematol 1990;75:

3 Robertson MJ, Ritz J. Biology and clinical relevance of human natural killer cells. Blood 1990;76:2421-38.

4 Soler J, Bordes R, Ortuño F, Montagud M, Martorell J, Pons C, et al. Aggressive natural killer cell leukaemia/ lymphoma in two patients with lethal midline granuloma. Br f Haematol 1994:86:659-62.

5 Parrado A, Rodríguez-Fernández JM, Casares S, Noguerol P, Plaza E, Parody R, et al. Generation of LAK cells in vitr in patients with acute leukemia. Leukemia 1993;7:1344-8.

6 Jacobs R, Stoll M, Stratmann G, Leo R, Link H, Schmidt RE. CD $16^{-} \mathrm{CD}^{-} 6^{+}$natural killer cells after bone marrow transplantation. Blood 1992;79:3239-44.

7 Weil-Hillman G, Fisch P, Prieve AF, Sosman JA, Hank JA Sondel PM. Lymphokine-activated killer activity induced by in vivo interleukin 2 therapy: predominant role for lymphocytes with increased expression of CD2 and Leu19 antigens but negative expression of CD16 antigens. Cancer antigens but negative expression of CD16 antigens. Cancer

8 Parrado A. Análisis de la actividad citolítica natural y las subpoblaciones linfocitarias en las leucemias agudas: efecto in vitro e in vivo de la interleucina-2. $\mathrm{PhD}$ thesis. Seville: University of Seville, 1994.

9 Sánchez MJ, Spits H, Lanier LL, Phillips JH. Human natural killer cell committed thymocytes and their relation to the T cell lineage. $\mathcal{F}$ Exp Med 1993;178:1857-66.

10 Miller JS, Alley KA, McGlave P. Differentiation of natural killer (NK) cells from human primitive marrow progenitors in a stroma-based long-term culture system: identificatio of a CD $34^{+} 7^{+}$NK progenitor. Blood 1994;83:2594-601.
First Department of Internal Medicine, Agia Olga Hospital, Athens, Greece

C Christopoulos

K Kottoris

E Anevlavis

Choremeion Oncology

Research Laboratory, Medical School,

Athens University,

Athens, Greece

V Mikraki

Correspondence to: Dr C Christopoulos, Vas. Alexandrou 7, Kifissia,

Athens, 14561 Greece.

Accepted for publication 4 September 1996

\title{
Presence of the bcr/abl rearrangement in a patient with chronic neutrophilic leukaemia
}

\author{
C Christopoulos, K Kottoris, V Mikraki, E Anevlavis
}

absence of the Philadelphia chromosome

Abstract

An 83 year old woman presented with a myeloproliferative disorder involving the myeloid and megakaryocytic lines, and characterised by mature neutrophil leucocytosis. There was a high/normal neutrophil alkaline phosphatase activity and features compatible with a diagnosis of chronic neutrophilic leukaemia (CNL). Southern blot analysis of the patient's DNA revealed the presence of the bcr/abl rearrangement. Combined with a previous report of detection of $\mathrm{Ph}^{1}$ chromo- 